\title{
CONTINUOUS VERSUS PATIENT-CONTROLLED EPIDURAL ANALGESIA FOR LABOUR ANALGESIA AND THEIR EFFECTS ON MATERNAL MOTOR FUNCTION AND AMBULATION
}

\section{Margarita Lovach-Chepujnoska ${ }^{1}$, Jordan Nojkov ${ }^{2}$, Slagjana Joshevska-Jovanovska ${ }^{1}$, Robert Domazetov ${ }^{1}$}

${ }^{1}$ Remedika Private General Hospital, Skopje, R. Macedonia

${ }^{2}$ University Orthopedic Surgery Clinic, Department of Anaesthesiology, Faculty of Medicine, Ss. Cyril and Methodius University, Skopje, R. Macedonia

Corresponding Author: Margarita Lovach-Chepujnoska, Remedika Private General Hospital, Skopje, R. Macedonia, Tel. +389 (0)2 754335 33, E-mail: margarita.lc@gmail.com

\begin{abstract}
Background and objectives: The advantages of patient-controlled epidural analgesia (PCEA) for delivery compared with continuous epidural analgesia (CEA) have been a point of interest in research obstetric anaesthesia for more than two decades.

The aim of this single blind randomized controlled study was to evaluate the incidence of motor block and ability to perform partial knee flexion in women who received CEA or PCEA.

Method: Fifty-one healthy nulliparous women were included in this study. After an initial dose and established sensory block at Th 10, parturients were randomized into two groups: group CEA (10 $\mathrm{ml} / \mathrm{h}$ ), and group PCEA (bolus $-5 \mathrm{ml}$, lockout interval -15 minutes, basal rate $-0 \mathrm{ml}$ ) with bupivacaine $0.08 \%$ and fentanyl $2 \mu \mathrm{g} / \mathrm{ml}$. The motor function of the lower limbs was evaluated by modified Bromage scale at regular hourly intervals until full cervical dilatation. The quality of analgesia was assessed using a visual analogue pain scale (VAPS) and maternal satisfaction. Mode of delivery, the total number of additional rescue boluses, foetal and neonatal outcomes were recorded.

Results: Motor block was significantly lower in the third $(33.3 \% v s .4 .35 \% ; \mathrm{p}=0.008)$, fourth $(57.9 \%$ vs. $6.3 \% ; \mathrm{p}=0.003)$ and fifth hour $(75.0 \%$ vs. $18.2 \% ; \mathrm{p}=0.001)$ in the PCEA group. Ambulation occurre in $18 \%$ in the CEA and $46 \%$ in the PCEA group $(\mathrm{p}=0.036)$. VAPS was with borderline significance in the second $(p=0.076)$ and significantly lower in the fourth hour $(p=0.034)$.

Conclusion: Compared with CEA, PCEA provided less motor block and better first-stage analgesia, which leads to the conclusion that patient-controlled analgesia techniques are the preferred model in obstetric anesthesia.
\end{abstract}

Key words: epidural analgesia, continuous, patient-controlled, motor block.

\section{Introduction}

Neuraxial techniques such as pure epidural or combined spinal-epidural for achieving initial block at started first-stage delivery are the most effective methods in obstetric analgesia. Considering the fact that the first and second stage of delivery may last several hours, and the initial dose of local anaesthetic given intrathecally or epidurally has a limited effect of 30-60 minutes, there is a need to maintain pain relief during labour until delivery. Modalities of maintaining analgesia during labour are: continuous infusion of local anaesthetic as the first and oldest method [1], controlled administration of boluses by the patient, i.e. patientcontrolled analgesia [2], or intermittent boluses of local anaesthetic that can be applied manually by staff or by computer programmed 
intermittent epidural boluses [3], as the most modern method in obstetric analgesia.

The advantages of continuous epidural analgesia (CEA) lie in the consistency in the delivery of drugs with pumps that are easily accessible and simple to operate. But on the other hand we have inflexible and sometimes inadequate analgesia, leading to increased consumption of local anaesthetic and profound motor block [4], and thus a greater number of instrumental vaginal deliveries.

Motor block caused by the epidural analgesia as one of the key factors for instrumental vaginal delivery has been the subject of many previous studies [5-10].

The distribution of the local anaesthetic into the epidural space depends on the mode of drug delivery. Namely, at the continuous infusion of the anaesthetic, the pressure generated in the epidural catheter is low, and the local anaesthetic in a form of a drop leaks only from the distal orifice of the epidural catheter [11]. In PCEA, the bolus is given with greater speed of delivery, which creates higher pressure in the epidural catheter and the local anaesthetic leaks from all three orifices of the catheter. This distribution affects the total dose of consumed local anaesthetic, and thus the degree of maternal motor block. Optimal use of epidural analgesia also depends on the concentration of the local anaesthetic. During the last decade the fact that the use of low concentrations of local anaesthetic (low-dose) in combination with opioids is the preferred model in obstetric analgesia, which maintains maternal motor function and enables ambulance during labour has already been established [12].

Maternal ambulance and the upright position of the parturient during the first stage of the delivery is a major advantage that allows gravity to facilitate descent and rotation of the foetus, enables the mother to be active during the childbirth and to use the bathroom. For these reasons, epidural analgesic techniques that do not affect the motor function of the mother are preferred [13].

This study was designed and conducted to test the hypothesis that PCEA compared with CEA could lead to a reduced incidence of motor block and instrumental vaginal deliveries, and at the same time to provide good qua- lity of analgesia and pain control during labour and delivery. The primary outcome of the study was the degree of motor block, while secondary outcomes were maternal ambulance and mode of delivery.

\section{Materials and methods}

Approval to conduct the study was provided by the Ethical Committee of the Remedika private general hospital in Skopje. Nulliparous women who planned to deliver at our hospital were sent study information during the $34^{\text {th }}$ gestational week. Further information was imparted by the duty anaesthesiologist prior to explaining the whole study. After written Informed Consent (IC) was obtained, 51 nulliparous women with single non-complicated pregnancy, gestational age $\geq 37$ weeks, scheduled for spontaneous delivery, were included in the study. Nulliparous women with a systemic disease (diabetes, hypertension, preeclampsia, and neurological diseases), chronic use of analgesics, body mass index $(\mathrm{BMI})>35$, coagulopathy and platelet count of $\leq 90 \times 10^{9}$ or multiple pregnancies were not eligible to participate.

At the time of request to start with analgesia, cervical dilation and vital parameters (noninvasive blood pressure, heart rate, and foetal heart rate) were recorded. Baseline pain scores were assessed using visual analogue pain scale (VAPS - $100 \mathrm{~mm}$ unmarked line with end-points labelled "no pain" and "worst imaginable pain"). The research included nulliparous women with cervical dilatation $3-5 \mathrm{~cm}$ and VAPS values between 50 and $100 \mathrm{~mm}$ at the peak of contraction.

All parturients were prehydrated with $500 \mathrm{ml}$ Ringer lactate solution. The epidural catheter was placed in a sitting position using midline approach at the L3-4 or L2-3 interspace. To identify the epidural space a loss of resistance to normal saline technique was used with B. Braun Perican, Touhy needle, bevel 18-g $\times 3_{1 / 2}$. A multi-orifice epidural catheter (Perifix catheter 20 -g $\times 1000 \mathrm{~mm}$ ) was inserted $4-5 \mathrm{~cm}$ in the epidural space. The position of the catheter was tested with $3 \mathrm{ml}$ lidocaine $1.5 \%$ to exclude intrathecal placement. During this initial procedure, an unblinded researcher opened a sequentially numbered opaque envelope with the group assignment. 
Following a test dose of lidocaine, all parturients received an initial loading epidural dose consisting of $0.08 \%$ bupivacaine and 2 $\mu \mathrm{g} / \mathrm{ml}$ fentanyl, $10-13 \mathrm{ml}$, according to the patient s body height. Noninvasive blood pressure was measured every 3 minutes during the first 15 minutes. Hypotension, defined as systolic blood pressure $<100 \mathrm{mmHg}$, or a decrease of more than $20 \%$ from the baseline, was treated with IV ephedrine, until achieving basal values.

Thirty minutes after the initial bolus dose and established bilateral symmetric block at Th10, parturients were divided into two groups: Group CEA and Group PCEA according to randomization. Parturients with asymmetric block (difference more than one dermatome) and those who had had VAPS $>4$ or required additional pain relief in the first 30 minutes were excluded from statistical analysis due to failed epidural block.

For the purpose of the study, we used pumps (B Braun Perfusor fm Type 871391) and the same epidural solution in both groups (bupivacaine $0.08 \%$ and fentanyl $2 \mu \mathrm{g} / \mathrm{ml}$ ). The epidural catheter was connected with a syringe through an antireflux valve to prevent possible reflux of local anaesthetic. All pumps were covered with an opaque portable bag assuring that the active investigator was blinded.

In the CEA group the pump was programmed to deliver continuous infusion of 10 $\mathrm{ml} / \mathrm{h}$, without the possibility of using an ondemand button. Programmed parameters of the PCEA pump were: bolus of $5 \mathrm{ml}$, lockout interval 15 minutes, without basal infusion rate, maximum volume of local anaesthetic of $20 \mathrm{ml}$ for 1 hour. All boluses in the PCEA group were delivered with the same rate of $200 \mathrm{ml} / \mathrm{h}$. Each parturient of the PCEA group was given written information on how to use the pump, and the concept of patient-controlled analgesia was verbally explained by the anaesthesiologist to each one. In this way, they were trained to press a button at a time when the pain disrupted their comfort, or when the pain intensified (VASP $\geq 4$ ). In both groups, inadequate analgesia was treated with additional manual boluses ( $5 \mathrm{ml}$ of the same solution) by an anaesthesialogist or nurse until achieving VASP $\leq 2$. In cases of need of more than two manual boluses during two consecutive hours, the concentra- tion of epidural solution was changed (bupivacaine $0.1 \%$, fentanyl $2 \mu \mathrm{g} / \mathrm{ml}$ ), while the protocol of the pump remained the same. Every additional manual bolus was recorded at the time when it was given.

Scores for the VAPS and motor block were at 60 minute intervals, by a blinded anaesthesiologist, until full cervical dilation was reached. Motor function was tested with the modified Bromage scale by Breen [14]: $1=$ complete block (inability to move feet and knees), 2 = almost complete block (move feet only), 3 = partial block (bends, but doesn't raise knees), 4 = bends and pulls knees in bed with weakness, $5=$ bends and pulls knees without weakness and $6=$ stands on feet with partially knee flexion). Each patient with a level of motor block 5 and 6 was able to stand on her feet, to move around the bed and use the bathroom only in the presence of medical personnel.

At the same regular intervals, sensory block, noninvasive blood pressure, heart rate, foetal heart rate, cervical dilation, oxytocin stimulation and adverse effects were recorded. After delivery, neonatal parameters, mode of delivery and maternal satisfaction $(100 \mathrm{~mm}$ line in which $0-20 \mathrm{~mm}=$ extremely dissatisfactory; $20-40 \mathrm{~mm}=$ dissatisfactory; $40-60 \mathrm{~mm}=$ partially satisfactory; $60-80 \mathrm{~mm}=$ satisfactory; $80-100 \mathrm{~mm}=$ very satisfactory) were recorded.

For statistical analysis, the SPSS statistical computer program (version 15.0) was used. Categorical data were presented in percentages, and the continuous parameters with the mean \pm standard deviation (SD). The comparison between the two groups of continuous parameters was made with a two-way t-test, while the categorical parameters with the Pearson Chi-square test. Using the data from previous studies [16, 17], we predicted that the size of the sample of 51 patients (CEA 27 and PCEA 24), would provide a power of $>0.8$ of significance to determine significant variance in the degree of motor block between the groups. For all tests, the value of $p<0.05$ was considered statistically significant. The comparison of several groups in the subgroup analysis was performed with the ANOVA test with post hoc Bonferoni correction. Post hoc analysis of some variables could not ben performed due to the small number of examinees (less than 2 in each of the groups). 


\section{Results}

Between January 2012 and September 2012, 58 pregnant nulliparious women were included in the study and divided into two groups: CEA $(\mathrm{n}=27)$ and PCEA $(\mathrm{n}=24)$. Seven parturients were excluded from the study; 3 - inadequate analgesia in the first 30 minutes (failed epidural block); 2 - asymmetric sensory block after the initial dose and 2 - missing data, so that 51 of them completed the full protocol.
There was no significant difference in the demographic characteristics of patients: age, body height, body weight, body mass index (BMI), ethnicity and gestational age. Obstetric and neonatal outcome and the number of instrumental vaginal deliveries and caesarean deliveries showed no statistically significant difference. The incidence of instrumental vaginal deliveries was $11.1 \%$ in CEA and $4.2 \%$ in PCEA group $(\mathrm{p}=0.351)$, Table 1 .

Table 1

Characteristics of parturuents, delivery and the neonatal outcome

\begin{tabular}{lccc}
\hline & CEA $(\mathbf{n}=\mathbf{2 7})$ & PCEA $(\mathbf{n}=\mathbf{2 4})$ & p-value \\
\hline Age & $30.89 \pm 4.23$ & $32.29 \pm 3.11$ & 0.271 \\
Gestational week & $39.04 \pm 1.09$ & $39.00 \pm 0.978$ & 0.749 \\
BMI $\left(\mathrm{kg} / \mathrm{m}^{2}\right)$ & $26.13 \pm 2.78$ & $26.60 \pm 3.04$ & 0.685 \\
\hline Cervix $(\mathrm{cm})$ & $3.26 \pm 0.86$ & $3.17 \pm 0.69$ & 0.749 \\
Duration & $289.04 \pm 144.70$ & $308.751 \pm 120.43$ & 0.601 \\
IVD & $3 / 11.11 \%$ & $1 / 4.16 \%$ & 0.351 \\
SC & $9 / 33.3 \%$ & $5 / 20.8 \%$ & 0.248 \\
pH newborn & $7.41 \pm 0.87$ & $7.40 \pm 0.56$ & 0.768 \\
Apgar 1 & $8.41 \pm 0.64$ & $8.46 \pm 0.78$ & 0.798 \\
Apgar 5 & $9.04 \pm 0.52$ & $9.13 \pm 0.85$ & 0.653 \\
\hline
\end{tabular}

BMI - Body Mass Index; SC - Section Caesarean; IVD - instrumental vaginal delivery

The critical value to determine the motor block was defined as score 4 on a Breen scale, as a patient with scores 5 and 6 has no limitation to the possibility to ambulate. At least once during analgesia, motor block occurred in $59.3 \%$ in the CEA group and $25 \%$ in the PCEA group. At full cervical dilation, the incidence of motor block was higher in CEA (15 of 27) compared with PCEA ( 3 of $24 ; p=0.001$ ). Comparison between the groups by using Pearson Chi-square test showed a statistically significant difference between the two groups in terms of the level of motor block in the third $(33.3 \%$ vs. $4.35 \%$; $\mathrm{p}=0.008)$, fourth $(57.9 \%$ $v s .6 .3 \% ; \mathrm{p}=0.003)$ and fifth hour $(75.0 \% v s$. $18.2 \%)(\mathrm{p}=0.001$; Table 2).

Table 2

Degree of motor block

\begin{tabular}{|c|c|c|c|c|c|c|c|c|c|}
\hline Breen & \multicolumn{2}{|c|}{3} & \multicolumn{2}{c|}{$\mathbf{4}$} & \multicolumn{2}{c|}{$\mathbf{5}$} & \multicolumn{2}{c|}{$\mathbf{6}$} & P \\
\hline & CEA & PCEA & CEA & PCEA & CEA & PCEA & CEA & PCEA & \\
\hline 1 hour & & & $13 / 48.1 \%$ & $9 / 37.5 \%$ & $14 / 51.9 \%$ & $12 / 50.0 \%$ & $0 / 0 \%$ & $3 / 12.5 \%$ & 0.156 \\
\hline 2 hour & & & $6 / 22.2 \%$ & $3 / 12.5 \%$ & $18 / 66.7 \%$ & $13 / 54.2 \%$ & $3 / 11.1 \%$ & $8 / 33.3 \%$ & 0.141 \\
\hline 3 hour & & & $8 / 33.3 \%$ & $1 / 4.35 \%$ & $12 / 50.0 \%$ & $10 / 43.5 \%$ & $4 / 16.7 \%$ & $12 / 52.2 \%$ & $\mathbf{0 . 0 0 8}$ \\
\hline 4 hour & & & $11 / 57.9 \%$ & $1 / 6.3 \%$ & $4 / 21.10 \%$ & $11 / 68.8 \%$ & $4 / 21.1 \%$ & $4 / 25.0 \%$ & $\mathbf{0 . 0 0 3}$ \\
\hline 5 hour & $1 / 8.3 \%$ & $0 / 0 \%$ & $9 / 75.0 \%$ & $2 / 18.2 \%$ & $2 / 16.7 \%$ & $8 / 72.7 \%$ & $0 / 0 \%$ & $1 / 9.1 \%$ & $\mathbf{0 . 0 1 8}$ \\
\hline 6 hour & & & $1 / 25.0 \%$ & $1 / 14.3 \%$ & $3 / 75.0 \%$ & $5 / 71.4 \%$ & $0 / 0 \%$ & $1 / 14.3 \%$ & 0.692 \\
\hline
\end{tabular}

Breen - modified Bromage scale. * Pay attention to the 3rd, 4th and 5th hour

An effect on the motor function of the legs occurred earlier in parturients who received the CEA compared with the PCEA group. The peak of the motor block in the CEA group coincided with the time of administration of additional manual boluses of local anaesthetic (third, fourth and fifth hour). 
The incidence of motor block at full cervical dilation was significantly higher in the CEA group (15 of 27), compared with the PCEA group (3 of 24$)(p=0.01)$, Figure 1 . Occurrence of motor block at full cervical dilation was associated with a greater number of instrumental deliveries and caesarean section $(p=0.03)$. The increased risk of instrumental vaginal delivery or c-section is associated with duration of labour and analgesia $(\mathrm{p}<0.001)$.

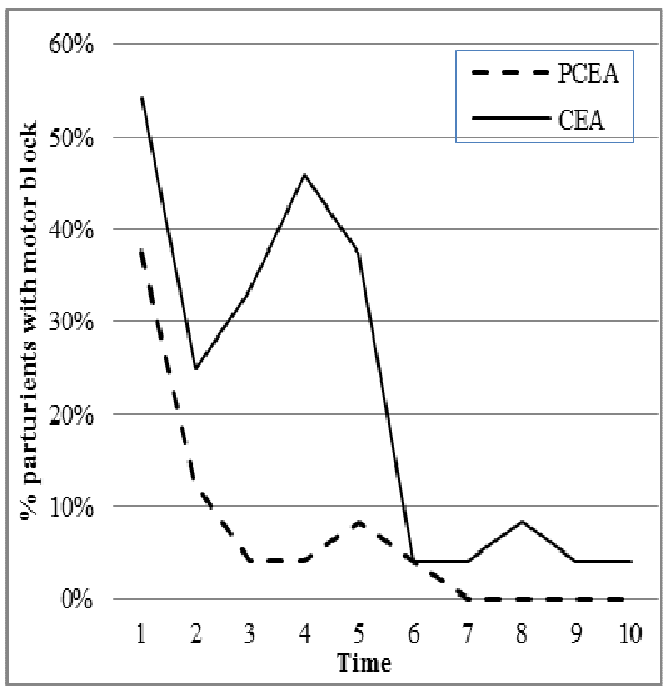

Figure 1 - Percentage of motor block
The number of patients who requested at least one additional manual bolus significantly differed in the groups: 11 of 27 in the CEA and 4 of 24 in the PCEA group $(p=0.02$; Table 3$)$. Ambulation was significantly higher $(\mathrm{p}=$ 0.036) in the PCEA group (Table 3). The VASP score was lower with a borderline significance in the second hour $(2.52 \pm 1.19$ vs. 1.88 $\pm 1.36 ; \mathrm{p}=0.076)$ and significantly lower in the fourth hour $(3.21 \pm 1.36 v s .2 .25 \pm 1.18 ; \mathrm{p}=$ $0.034)$ in the group of patients with PCEA.

Table 3

Characteristics of analgesia

\begin{tabular}{lccc}
\hline & $\begin{array}{c}\text { CEA } \\
(\mathbf{n}=\mathbf{2 7})\end{array}$ & $\begin{array}{c}\text { PCEA } \\
(\mathbf{n = 2 4 )}\end{array}$ & $\begin{array}{c}\text { p-va- } \\
\text { lue }\end{array}$ \\
\hline $\begin{array}{l}\text { Additional manual } \\
\text { bolus }\end{array}$ & 11 & 4 & $\mathbf{0 . 0 2}$ \\
Ambulation & & & \\
\hline VASP & 5 & 11 & $\mathbf{0 . 0 3 6}$ \\
\hline Time 0 $(\mathrm{n}=51)$ & $6.74 \pm 0.81$ & $6.83 \pm 0.92$ & 0.704 \\
1 hour $(\mathrm{n}=51)$ & $0.96 \pm 1.09$ & $1.00 \pm 1.14$ & 0.906 \\
2 hour (n=51) & $2.52 \pm 1.19$ & $1.88 \pm 1.36$ & $\mathbf{0 . 0 7 8}$ \\
3 hour (n=47) & $3.13 \pm 1.39$ & $2.78 \pm 1.17$ & 0.367 \\
4 hour (n=35) & $3.21 \pm 1.36$ & $2.25 \pm 1.18$ & $\mathbf{0 . 0 3 4}$ \\
5 hour (n=23) & $2.50 \pm 0.80$ & $2.45 \pm 1.13$ & 0.912 \\
\hline
\end{tabular}

VAPS - Visual Analogue Pain Scale

Table 4

Studies comparing CEA vs PCEA or PEIB

\begin{tabular}{|c|c|c|c|}
\hline References & $\mathrm{N}$ groups & CEA & $\begin{array}{l}\text { Bolus technique } \\
\text { (PCEA or PEIB) }\end{array}$ \\
\hline Van der Vyver et al. 2002 - meta analysis & 12 RCTs (640 patients) & & less motor block \\
\hline Chen et al. 2006 & $98 / 85$ & & less motor block \\
\hline Capogna et al. 2011 & $75 / 70$ & & less motor block \\
\hline George et al. 2013 - meta analysis & 9 RCTs (694 patients) & & less motor block \\
\hline Fettes et al. 2006 & $20 / 20$ & no difference & no difference \\
\hline Wong et al. 2010 & $63 / 63$ & & Less (not significant) \\
\hline
\end{tabular}

\section{Discussion}

The main goal of our study was to determine whether the pattern of epidural analgesia affects the motor function of the mother, and therefore the ability to move during delivery. The results show significantly less motor block in patients in the PCEA compared with those in the CEA group, which is consistent with several analysed studies [13-15]. Patients who received PCEA had greater mobility during labour. The role of mobility in the first stage of the delivery is still not precisely defined. An upright position during childbirth increases the likelihood of spontaneous delivery [16]. Assumed mechanisms directly influence the gravity that supports the positive physiological feedback neuroendocrine mechanism (release of prostaglandins and Ferguson's reflex) [17] and improved blood flow through the uterus by reduced aorto-caval compression which is profound in the supine position. The end result is stronger and more regular contractions that contribute to a faster spontaneous fetal expulsion. 
In literature, there are controversial results about the connection of the type of analgesia and degree of motor block. Reported motor block associated with the type of epidural analgesia has been confirmed in several studies $[13,15]$ in which continuous epidural techniques with programmed intermittent epidural boluses (PIEB) were compared. Although in our study we did not use the most modern model of PIEB, these studies can be taken for reference, because as in our study, two models have been compared: continuous and bolus epidural analgesia. But in the study by Chua and Sia [18], PIEB and CEA have been used but motor block has not been reported yet. Although this is a case of respected authors and study, we must take into account the fact that they have evaluated the motor block only until the moment of additional manual boluses (defined as END point). Average duration of analgesia to the END point was 3 hours. The study by Fettes [19], when comparing PIEB with CEA, does not report variance in the affection of the maternal motor function, but the concentration of local anaesthetic (ropivacaine $0.2 \%$ ) used was significantly higher compared to the other studies.

In 2002, van der Vyver et al [6] systematically reviewed 12 RCTs of traditional PCEA versus CEI. The measurement of motor power or weakness was different in each of the studies, but the final report presented less motor block in the PCEA compared to the CEA group $(p=0.003)$. Eleven years later, in 2013, another systematic review and meta analysis [20] of IEB (intermittent epidural boluses) versus CEI (continuous epidural infusion) was published. One of these studies [13] assessed motor block using the Bromage score modified by Breen and after adjustment to a traditional Bromage score the results showed no statistically significant difference (Odds ratio [95\% confidence interval] 0.47).

Both techniques, CEA and PCEA, appear to be safe for the mother and neonate. Most frequently reported side effects were hypotension $(4.7 \%)$, nausea (9.3) and pruritus (37.9\%). These side effects, as easily treatable, do not affect maternal and neonatal outcomes and our results did not differ from reports of this systematic review. Reported incidence of post puncture headache (PPH), as a more serious complication, is $1 \%$. In our study PPH did not happen at all. In a review by Ruppen and colleagues [21] of 27 studies published after 1990, the serious adverse events involving 1,37 million women were analysed and the reported risk estimations are as follows: epidural haematoma 1 in 168,000; deep epidural infection 1 in 145,000 ; persistent neurologic injury 1 in 240,000 ; transient neurologic injury 1 in 67,000 .

The results obtained on instrumental vaginal delivery do not match with several previous studies $[4,20,21]$, in which the incidence of instrumental delivery is associated with the model of analgesia. Perhaps in the future, for a more subtle evaluation of this parameter, we will need to do research with larger sample size. However, in our study we found a strong correlation between the number of instrumental deliveries and caesarean section with the incidence of motor block only in the period of full cervical dilation $(p=0.03)$ and correlation with the duration of analgesia, that is the first stage of delivery $(\mathrm{p}<0.001)$.

The Modified Bromage Scale, which we used to assess the motor block, is more sensitive when compared with the Bromage scale used in most studies [14, 20], so with this evaluation we could have made a more sensitive distinction between the different degrees of motor block. However, in these studies the primary outcome was not the effect of epidural analgesia on maternal motor function, but their focus was on other parameters that affect the quality of analgesia. In a study published in 2011 [13] the primary outcome was the motor block and in this study Breen modification of Bromage was used. The outcome showed that PIEB compared with CEA leads to reduced motor block and instrumental vaginal deliveries.

Given the fact that PCEA is not a generally accepted epidural technique in Macedonia, these initial investigations have certain drawbacks and limitations. The total volume of consumed local anaesthetic as one of the key factors for the degree of motor block was not the focus of interest of this study. Motor block was evaluated only in the lower limbs, although in fact the activity of pelvic or sacral mus- 
culature is of greater importance. Measurement of pelvic tonus in clinical practice is extremely difficult, so that the mobility of the lower extremities is a valid indicator of pelvic muscle function.

Variations of the model of PCEA can be in many parameters: the type of local anaesthetic, concentration, bolus volume, lockout intervals, with or without a continuous background infusion, intrathecal or pure epidural initial dose. Epidural solution leads to analgesia through diffusion of the drug through the extraneural into the intraneural space. Motor fibres are almost two times thicker and longer than the sensory thin and short fibres. Diffusion gradient becomes quickly reversed in the sensory fibres. Therefore, if the local anaesthetic is of low concentration and if given in boluses, not continuously, the possibility of blocking the motor nerves is very small. The used concentration of bupivacaine in this study was $0.08 \%$, the concentration that is routinely used in the hospital where the study was conducted. Further reduction in the concentration of $0.0625 \%$ and abandoning the concept of continuous epidural infusion may contribute to improve the quality of obstetric analgesia.

\section{Conclusion}

Patient-controlled epidural techniques used to maintain analgesia during labour lead to reduced motor block and increased opportunity for ambulation in an upright position. The evaluation of the motor block through the Breen scale provides an optimal assessment of the maternal motor function in labour and the ability to move safely. PCEA provides a good quality of labour analgesia during the first stage of delivery.

\section{REFERENCES}

1. Bleyaert A, Soetens M, Vaes L, Van Steenberge L, Van der Donck A. Bupivacaine, 0,125 per cent, in obstetric epidural analgesia: Experience in three thousand cases. Anesthesiolgy. 1979; 51: 435-8.

2. Gambling DR, Yu P, Cole C, McMorland GH, Palmer L A. Comparative study of patient controlled epidural analgesia (PCEA) and continuous infusion epidural analgesia (CIEA) during labour. Can J Anaesth. 1988; 35: 249-54.

3. Sia AT, Lim Y, Ocampo CE. Computer-integrated patient-controlled epidural analgesia: a preliminary study on a novel approach of providing pain relief in labour. Singapore Med J. 2006; 47: 951-6.

4. Wong CA, Ratliff JT, Sullivan JT, Scavone BM, Toledo P, McCarthy RJ. A randomized comparation of programmed intermittent epidural bolus with continous epidural infusion for labor analgesia. Anesth Analg. 2006; 102: 904-9.

5. Petry J, Vercauteren M, Van Mol I, Van Houwe P, Adriaensen HA. Epidural PCA with bupivacaine $0.125 \%$, sufentanil 0.75 microgram and epinephrine $1 / 800.000$ for labor analgesia: is a background infusion beneficial? Acta Anaesthesiol Belg. 2000; 51(3): 163-6.

6. M. van der Vyver, S. Halpern and G. Joseph. Patientcontrolled epidural analgesia versus continuous infusion for labour analgesia: a meta-analysis. $\mathrm{Br} \mathrm{J}$ Anaesth. 2002; 89: 459-65.

7. Niels Koopmans, Götz J. K. Wietasch and Michel M. R. F. Struys. Patient-Controlled Epidural Analgesia regimens for labor analgesia: Background infusion or demand-only? Anesth Analg July. 2009; 109: 284 91.

8. Srivastava U, Gupta A, Saxena S, Kumar A, Singh S, Saraswat N, Mishra AR, Kannaujia A, Mishra S. Patient Controlled Epidural Analgesia during labour: Effect of addition of background infusion on quality of analgesia \& maternal satisfaction. Indian J Anaesth. 2009; 53(6): 649-53.

9. Stephen H. Halpern and Brendan Carvalho. PatientControlled Epidural Analgesia for labour. Anesth Analg. 2009; 108(3): 921-8.

10. Boselli E, Debon R, Cimino Y, Rimmele T, Allaouchiche B, Chassard D. Background infusion is not beneficial during labor patient-controlled analgesia with $0.1 \%$ ropivacaine plus $0.5 \mathrm{microg} / \mathrm{ml}$ sufentanil. Anesthesiology. 2004; 100(4): 968-72.

11. Kaynar A. Murat. Epidural Infusion: Continuous or Bolus? Anesth Analg. 1999; 89: 534-540.

12. Wilson MJ, Cooper G, MacArthur C, Shennan A. Comparative Obstetric Mobile Epidural Trial (COMET) study group UK. Effect of low dose mobile versus traditional epidural technique on mode of delivery: a randomized controlled trial. Anesthesiology. 2002; 97(6): 1567-75.

13. Capogna G, Camorcia M, Stirparo S, Farcomeni A. Programmed intermittent epidural bolus versus continous epidural infusion for labor analgesia: The effects of maternal motor function and labor outcome. A randomized double-blind study in nulliparous women. Anesth Analg. 2011; 113: 826-31.

14. Breen TW, Shapiro T, Glass B, Foster-Payne D, Oriol NE. Epidural anesthesia for labor in an ambulatory patient. Anesth Analg. 1993; 77: 919-24.

15. Lim Y, Sia AT, Ocampo C. Automated regular boluses for epidural analgesia: a comparison with continuous infusion. Int Obstet Anesth. 2005; 14: 305-9.

16. Wilson MJA, MacArthur C, Cooper GM, Shennan A. Ambulation in labour and delivery mode: a randomised controlled trial of high-dose vs mobile epidural analgesia. Anaesthesia. 2009; 64: 266-72. 
17. Martin EJ, Ruth DJ. Caring for the laboring woman. In: Kenedy BB, Ruth DJ, Martin EJ, editors. Intrapartum manamgement modules. $5^{\text {th }}$ ed. Philadelphia: Wolter Kluwer Lippincott Williams \& Wilkins. 2009. p. 134-5.

18. Chua SM, Sia AT. Automated intermittent epidural boluses improve analgesia induced by intrathecal fentanyl during labour. Can J Anaesth. 2004; 51: 581-5.

19. Fettes PD, Moore CS, Whitesede JB, McLeod GA, Wildsmith JA. Intermittent vs continous administration of epidural ropivacaine with fentanyl for analgesia during labour. Brit J Anaesth. 2006; 97: 35964.

20. George RB, Allen TK, Habib AS. Intermittent epidural bolus compared with continuous epidural infusions for labor analgesia: A Systematic Review and Meta-Analysis. Anesth Analg. 2013; 116: 133-44.

21. Ruppen W, Derry S, McQuay H, Moore A. Incidence of epidural hematoma, infection, and neurologic injury in obstetric patients with epidural analgesia/anesthesia. Anesthesiology. 2006; 105: 394-9.

22. Beilin Y, Guinn NR, Bernestein HH, Zahn J. Local anaesthetics and mode of delivery: bupivacaine versus ropivacaine versus levobupivacaine. Anesth Analg. 2007; 105: 756-63.

23. Halpern S. Recent advances in patient -controlled epidural analgesia. Curr Opion Anesth. 2005; 18: 247-51.

24. Sheng-Huan Ch. et al. Comparison of Patient-controlled Epidural Analgesia and Continuous Epidural Infusion for Labor Analgesia. Chang Gung Med J. 2006; 29: 576-82.

25. Sia AT, Lim Y, Ocampo CE. Computer-integrated patient-controlled epidural analgesia: a preliminary study on a novel approach of providing pain relief in labour. Singapore Med J. 2006; 47: 951-56.

26. Sia AT, Lim Y, Ocampo C. A comparison of basal infusion with automatic mandatory boluses in parturient-controlled epidural analgesia during labor. Anesth Analg. 2007; 104: 673-38.

27. Toledo P, Sun J, Grobman WA, Wong CA, Feinglass J, Hasnain-Wynia R. Racial and ethnic disparities in neuraxial labor analgesia. Anesth Analg. 2012; 114(1): 172-78.

28. Jiménez-Puente, et al. Ethnic differences in the use of intrapartum epidural analgesia. BMC Health Services Research. 2012; 12: 207-11.

29. Christiaens, et al. Pain acceptance and personal control in pain relief in two maternity care models: a cross-national comparison of Belgium and the Netherlands. BMC Health Services Research. 2010; 10: 268-70.

30. Tasnim S. Perception about Pain Relief During Normal Labour Among Health Care Providers Conducting Delivery. Med Today. 2010; 22(1): 20-23.

31. Glance et al. Racial Differences in the Use of Epidural Analgesia for Labor. Anesthesiology. 2007; 106: 19-25.
32. Bauchat R. J, et al. Prior lumbar discectomy surgery does not alter the efficacy of neuroaxial labour analgesia. Anesth Analg. 2012; 115: 348-53.

33. Unintentional Dural puncture with a Touhy Needle Increases Risk of Chronic Headache. Anesth Analg. 2012; 115: 124-32.

34. Can S. O, Yilmaz A. A, Hasdogan M, Alkaya F, Turhan C. S, Can F. M, Alanoglu Z. Has the quality of abstracts for randomised controlled trials improved since the release of Cosolidated Standards of reporting Trial guideline for abstract reporting? A survey of four high-profile anaesthesia journals. Eur J Anaesthesiol. 2011; 28: 485-92.

Резиме

\section{КОНТИНУИРАНА НАСПРОТИ ПАЦИЕНТ- КОНТРОЛИРАНА ЕПИДУРАЛНА АНАЛГЕЗИЈА И ВЛИЈАНИЕ ВРЗ МОТОРНАТА ФУНКЦИЈА И МОБИЛНОСТ НА МАЈКАТА}

\section{Маргарита Ловач-Чепујноска ${ }^{1}$, Јордан Нојков $^{2}$, Слаѓана Јошевска-Јовановска ${ }^{1}$, Роберт Домазетов ${ }^{1}$}

\footnotetext{
${ }^{1}$ Приватна општа болница „Ремедика“, Скопје, Р. Македонија

${ }^{2}$ Клиника за ортопедски болести, Медицински факултет, Универзитет „Св. Кирил и Методиј“, Скопје, Р. Македонија
}

Вовед: Предностите на пациент-контролираната епидурална аналгезија (ПКЕА) за породување споредена со континуираната епидурална аналгезија (КЕА) се предмет на истражувања во акушерската анестезија повеќе од две децении.

Целта на студијата беше да ја евалуираме инциденцата на моторен блок и способноста за парцијално клекнување кај трудници кои примиле КЕА или ПКЕА.

Мейод: Во студијата беа вклучени 51 здрава трудница. По давање на иницијалната доза и постигнатиот сензорен блок на ниво $\mathrm{Th}$ 10, трудниците беа рандомизирани во две групи: група КЕА $(10 \mathrm{ml} / \mathrm{h})$ и група ПКЕА (болус од 5 $\mathrm{ml}$, интервал помеѓу два болуси од 15 минути, базална инфузија $0 \mathrm{ml} / \mathrm{h}$ ), со анестетички раствор од bupivacaine $0,08 \%$ и fentanyl $2 \mu \mathrm{g} / \mathrm{ml}$. Моторната функција на долните екстремитети беше евалуирана по модифицираната скала на Bromage на регуларни временски интервали на еден час, до комплетна цервикална дилатација. Квалитетот на аналгезијата беше проверуван со 
Визуелната скала на болка (ВАСБ) и сатисфакција на мајката. На крај на породувањето беа нотирани начинот на породување, вкупен број дополнителни болуси и карактеристики на новороденото.

Резулйайи: Моторниот блок беше значајно понизок во третиот $(33,3 \% v s .4,35 \%$; $\mathrm{p}=$ $0,008)$, четвртиот $(57,9 \%$ vs. $6,3 \% ; p=0,003)$ и петтиот час $(75,0 \% v s .18,2 \% ; p=0,001)$ во групата пациенти со ПКЕА. Мобилноста на трудниците беше забележана кај 18\% во КЕА и 46\% кај ПКЕА групата $(p=0.036)$. ВАСБ беше со гра- нична значајност во вториот час $(\mathrm{p}=0,076)$ и значајно помала во четвртиот час $(\mathrm{p}=0,034)$ кај трудниците од групата ПКЕА.

Заклучок: ПКЕА споредена со КЕА резултира со намалена појава на моторен блок и подобра аналгезија во првото родилно време, што води кон заклучок дека пациент-контролираните техники на аналгезија се префериран модел во акушерската анестезија.

Клучни зборови: епидурална аналгезија, континуирана, пациент-контролирана, моторен блок. 